Journal of Engineering and Applied Sciences 7 (2): 207-214, 2012

ISSN: $1816-949 \mathrm{X}$

(C) Medwell Journals, 2012

\title{
Monitoring Crime Rates with Control Charts Using GIS Classifications
}

\author{
${ }^{1}$ Bello, ${ }^{2}$ S.U. Gulumbe, ${ }^{3}$ S.A. Yelwa and ${ }^{3}$ M.M. Badamasi \\ ${ }^{1}$ Department of Mathematics and Statistics, Hassan Usman Katsina Polytechnic, Katsin, Nigeria \\ ${ }^{2}$ Department of Mathematics, Usmanu Danfodio University, Sokoto, Nigeria \\ ${ }^{3}$ Department of Geography, Nigeria
}

\begin{abstract}
Monitoring crime rate with statistical tools and modern scientific and technological methods determine the safety index or otherwise of a geographical area. This study explores the use of GIS classifications and mean and range charts for monitoring crime rates in a geographical area. The standard charts were constructed using the crime rates of the median levels of crimes from GIS classification of Katsina state crime data. The historical mean can be use to monitor the levels of the crimes in the future period.
\end{abstract}

Key words: Crime, property, GIS, mean, range, charts, Nigeria

\section{INTRODUCTION}

There is no universal definition for crime. This is as a result of changes in social, political, psychological and economic conditions. An act may be a crime in one society but not in another (Feldman, 1997; Danbazau, 2007). In a strict legal definition however, a crime is a violation of criminal law which in most societies can be defined broadly as any act or omission forbidden law on pain of punishment (Carvell and Swinfen, 1970). The threat of crime to the society is impossible to ignore. It undermines the social fabric of society, by first eroding the sense of safety and security. It represents an immediate physical and moral threat to particular individuals (Louis et al., 1981). However, crime is an inescapable reality in human life, therefore no national characteristics, no political regime, no system of law, police or justice has rendered a country exempt from crime (Radzinowicz and King, 1977).

Despite the fact that crime is inevitable in a society Durkheim (1933), various controlling and preventive measures had been taken and still being taken to reduce the menace. The application of statistical, scientific and technical methods in crime monitoring, assessment, prevention and control has proved to be well effective. The first attempt to analyze crime data statistically seems to have been done by Ahamad (1967).

$\mathrm{He}$ used Principal Component Analysis (PCA) to analyse eighteen criminal offences for Great Britain for the years 1950-63. The PHD dissertation entitled analysis of low-probability count data with applications in crime analysis by Borowick (1997) is a good application of statistical tools on crime analysis. Tsiamtsiouri and Panaretos (1999) have utilized time series, cluster analysis and PCA to analyse Greek crime data. Rencher (2002) and Hardle and Zdenek (2007) have used cluster analysis to analyse the reported crimes in United State. The applications of Geographic Information System (GIS) and control charts are very important in mapping areas of different distributions of crime rates and in monitoring crime data, respectively.

McGuffog et al. (2001) have explored the use of GIS for examining crime occurrence in Brisbane, Australia. Savoie (2008) has also used GIS to determine the spatial distribution of violent crime incidences in Regina and robbery incidences in Winnipeg, Canada.

Fajemirokun et al. (2006) have utilised GIS in mapping crime in Victoria Island, Lagos. This study explores the use of GIS and mean and range control charts in monitoring crime rates using Katsina state crime data.

\section{MATERIALS AND METHODS}

The crime data for 36 Local Government Areas (LGAs) of Katsina state was collected from the Statistics F Department of the Nigeria Police Force, Katsina state command. For identification, the arrangement of the LGAs that would appear as points in the control chart is in the order: Bakori, Batagarawa, Batsari, Baure, Bindawa, Charanchi, Dandume, Danja, Danmusa, Daura, Dutsi, Dutsinma, Faskari, Funtua, Ingawa, Jibia, Kafur, Kaita, Kankara, Kankia, Katsina, Kurfi, Kusada, Maiaduwa, Malumfashi, Mani, Mashi, Matazu, Musawa, Rimi, Sabuwa, Safana, Sandamu and Zango LGAs. The state is

Corresponding Author: Bello, Department of Mathematics and Statistics, Hassan Usman Katsina Polytechnic, Katsin, Nigeria 
divided into three Area Commands (ACs), Katsina AC1, Funtua AC2 and Funtua AC3. The data consists of four crimes against persons reported to the police for the period 2006-2008.

The crimes are murder, rape, Grievous Hurt and Wounding (GHW) and assault. The frequencies for each crime were averaged $>3$ years in the study period to control for anomalous years when there may have been an unexplained spike or fall in crime levels prior to the statistical analysis. The value for each crime is converted to crime rate per 100,000 populations of the LGA (Kpedekpo and Arya, 1981) and is calculated as:

$$
\text { Crime rate }=\frac{\text { No.of crime committed }}{\text { Population of the LGA }} \times 100,000
$$

Geographic Information System (GIS): The mapping of the crime for the spatial analysis was accomplished using GIS software. The software is ArcView GIS 3.2a, copyright 1990-2000, Environmental System Research Institute, Inc. The GIS images of four average crimes against persons in Katsina state from 2006-2008 are displayed in section three.

Control chart: A control chart is a statistical device principally used for the study and control of repetitive process (Duncan, 1986). However in this study, the control chart is not monitoring the repetitive process that it is not monitoring crime rate in a sequential time period but it is monitoring crime rate in a given geographical area at a particular period. The two control charts used in this study are mean and range charts. Mean chart portrays fluctuation in the sample means and identify sample means that indicate that the process is out of control (Lind and Mason, 1997). If chart is being used to study past data, the central line is set at $\overline{\mathrm{x}}$, the average of all the data. The Upper Control Limit (UCL) and Lower Control Limit (LCL) usually are $3 \hat{\sigma}_{\overline{\mathrm{z}}}$ limits above and below where $\hat{\sigma}_{\overline{\mathrm{z}}}$ is an estimate of $\sigma_{\mathrm{x}}$ derived from the fast data. If the chart is being used to control current data, the central line may be a standard value $\overline{\mathrm{x}}$ " derived from the fast data or selected from the management to attain certain objectives (Duncan, 1986). The formulas for control limits are: For charts analyzing past data:

$$
\mathrm{UCL}=\overline{\overline{\mathrm{X}}}+\frac{3 \hat{\sigma}}{\sqrt{\mathrm{n}}} \text { and } \mathrm{LCL}=\overline{\overline{\mathrm{X}}}-\frac{3 \hat{\sigma}}{\sqrt{\mathrm{n}}}
$$

For charts for attaining current control:

$$
\mathrm{UCL}=\overline{\mathrm{X}}^{\prime \prime}+\frac{3 \sigma^{\prime \prime}}{\sqrt{\mathrm{n}}} \text { and } \mathrm{LCL}=\overline{\mathrm{X}}^{\prime \prime}-\frac{3 \sigma^{\prime \prime}}{\sqrt{\mathrm{n}}}
$$

The range chart shows variation in the ranges of the samples. The upper and lower limits for the range chart can be determine by:

$$
\mathrm{UCL}=\mathrm{D}_{4} \overline{\mathrm{R}} \text { and } \mathrm{LCL}=\mathrm{D}_{3} \overline{\mathrm{R}}
$$

where, $D_{3}$ and $D_{4}$ are factors from Table. This analysis is not time series oriented and therefore, th subgroups are the LGAs and the measurements are the crimes.

The objective is to identify the LGAs that have very high crime rate by falling above the UCL. Unlike the industrial control chart, a LGA has commendable crime rate by falling below the central line. That is the lower a point below the central line, the lower the crime rate and the safer the LGA is. However, the higher a point above the central line, the higher the crime rate and the unsecured the LGA is.

\section{RESULTS AND DISCUSSION}

The aim of the government and policing agency are to promote safety and safeguard the lives of the populace and this is achieve by reducing the rate of crime to a certain level.

Since, criminal activities are unavoidable in a society and the outcomes of any Crime Control Programme may not be assessed at zero level instantly, there is need to start assessing criminal activities from very higher levels to moderate levels and finally to lower levels.

Researchers now construct the mean and range charts for median crime rates as standard measure of monitoring criminal activities in the future years using crime rates of LGAs with median crime rates from GIS classifications. The mean and range charts for the murder cases in Katsina state is plotted on Fig. 1. The values for most of the LGAs falls below the central line and Charanchi LGA (point 6) fall $>3.00$ sigmas from UCL.

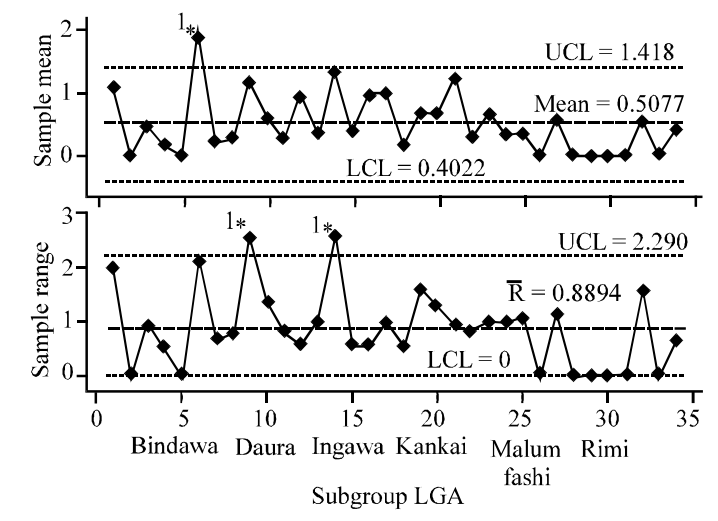

Fig. 1: Mean and range charts for murder cases in Katsina state 


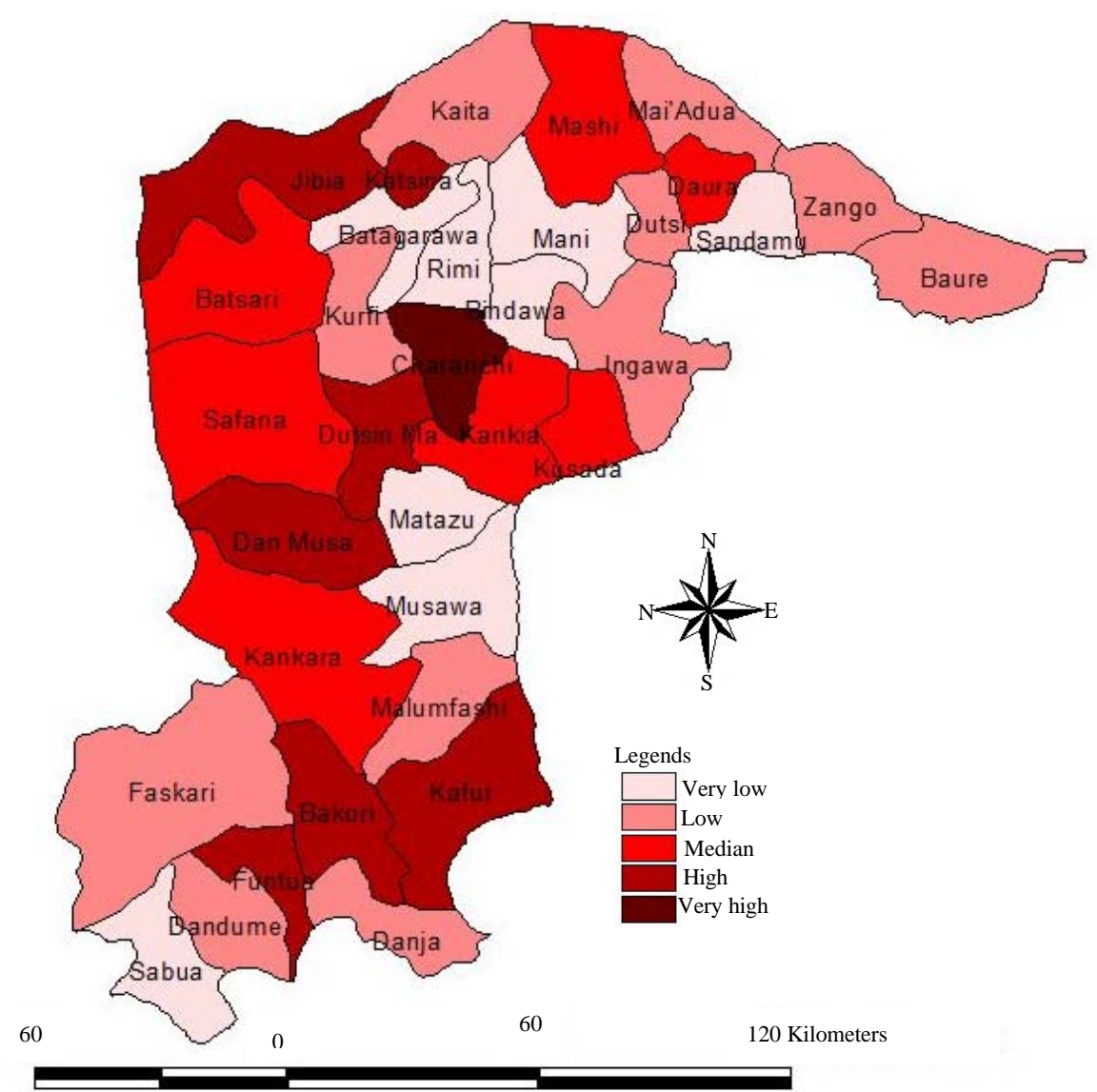

Fig. 2: Average murder rates in Katsina state 2006-2008

The range chart shows Danmusa and Funtua LGAs have much variation of murder cases $>3$ years. The above control is influence by the points far above and far below the central line, researchers determine the LGAs withmedian crime rate from GIS image in Fig. 2.

The LGA with high very higher rate of murder cases from Fig. 2 is Charanchi LGA and is followed by Katsina, Jibia, Dutsinma and Danmuasa from ACl, Funtua, Bakori and Kafur from $\mathrm{AC} 2$ with the higher rates.

The LGAs with median rates are Mashi, Daura, Kankia and Kusada from AC3, Batsari and Safana from $\mathrm{ACl}$ and Kankara from AC2. The LGAs with very lower rates of the crime are Bindawa, Mani and Sandamu from AC3, Musawa, Matazu and Sabuwa from AC2, Batagarawa and Rimi from $\mathrm{ACl}$.

$\mathrm{ACl}$ and 2 have the higher rates of the crime than the AC3. Using the values for LGAs with median rates, the mean and range charts are constructed in Fig. 3 as

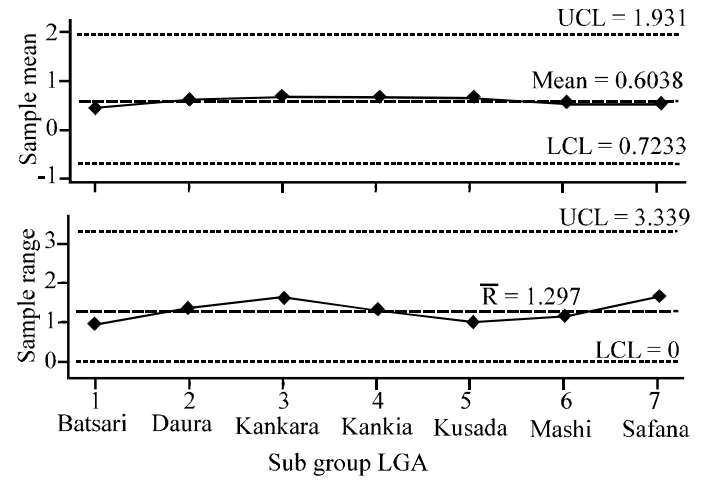

Fig. 3: Standard measure of monitoring murder cases in Katsina state

standard measure of monitoring murder cases in the state. The historical mean value is 0.6038 . The mean and range charts for the rape cases in Katsina state is plotted on Fig. 4. The values for most of the LGAs falls below the central line and Funtua, Jibia and Katsina LGAs fall 
$>3.00$ sigmas from center line which is above the UCL. The range chart shows Danja, Funtua and Kurfi LGAs have much variation of rape cases $>3$ years. The charts have many LGAs beyond the control limits and much variation

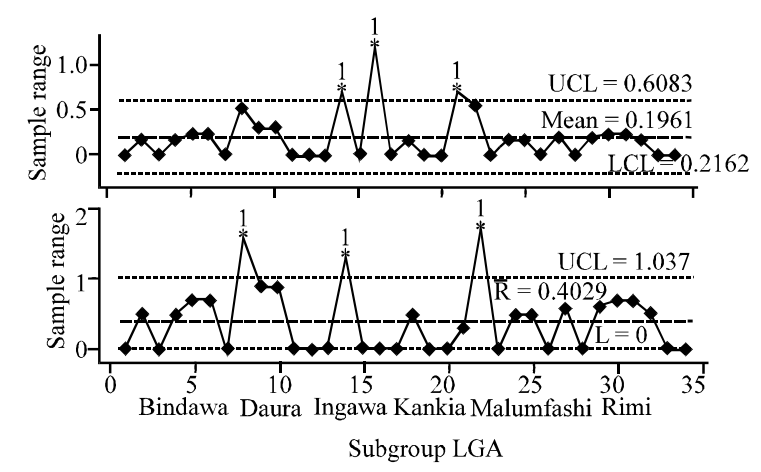

Fig. 4: Mean and range charts for the rape cases in Katsina state over the period, the mean and range charts for the LGAs with median rape cases from the GIS classifications is constructed as a standard measure.

From Fig. 5, the LGA with very higher rate of rape cases is Jibia LGA whereas Danja and Funtua fromAC2, Kurfi and Katsina from $\mathrm{ACl}$ have the higher rates. The crime has median rates in Daura from AC3 and Danmusa $\mathrm{ACl}$ and very lower rates in Ingawa, Dutsi, Mani, Kusada, Kankia, Sandamu and Zango from AC3, Dandume, Faskari, Bakori, Kafur and Kankara from AC2, Batsari and Dutsinma from $\mathrm{ACl}$.

$\mathrm{ACl}$ has the highest rate of the crime in the state while AC3 has the lowest. From the GIS classification, the mean and range charts for the LGAs with median and low rape cases are constructed in Fig. 6 as standard measure of monitoring rape cases in the state.

The historical mean value is 0.2095 . The mean and range charts for GHW cases in Katsina state is plotted on

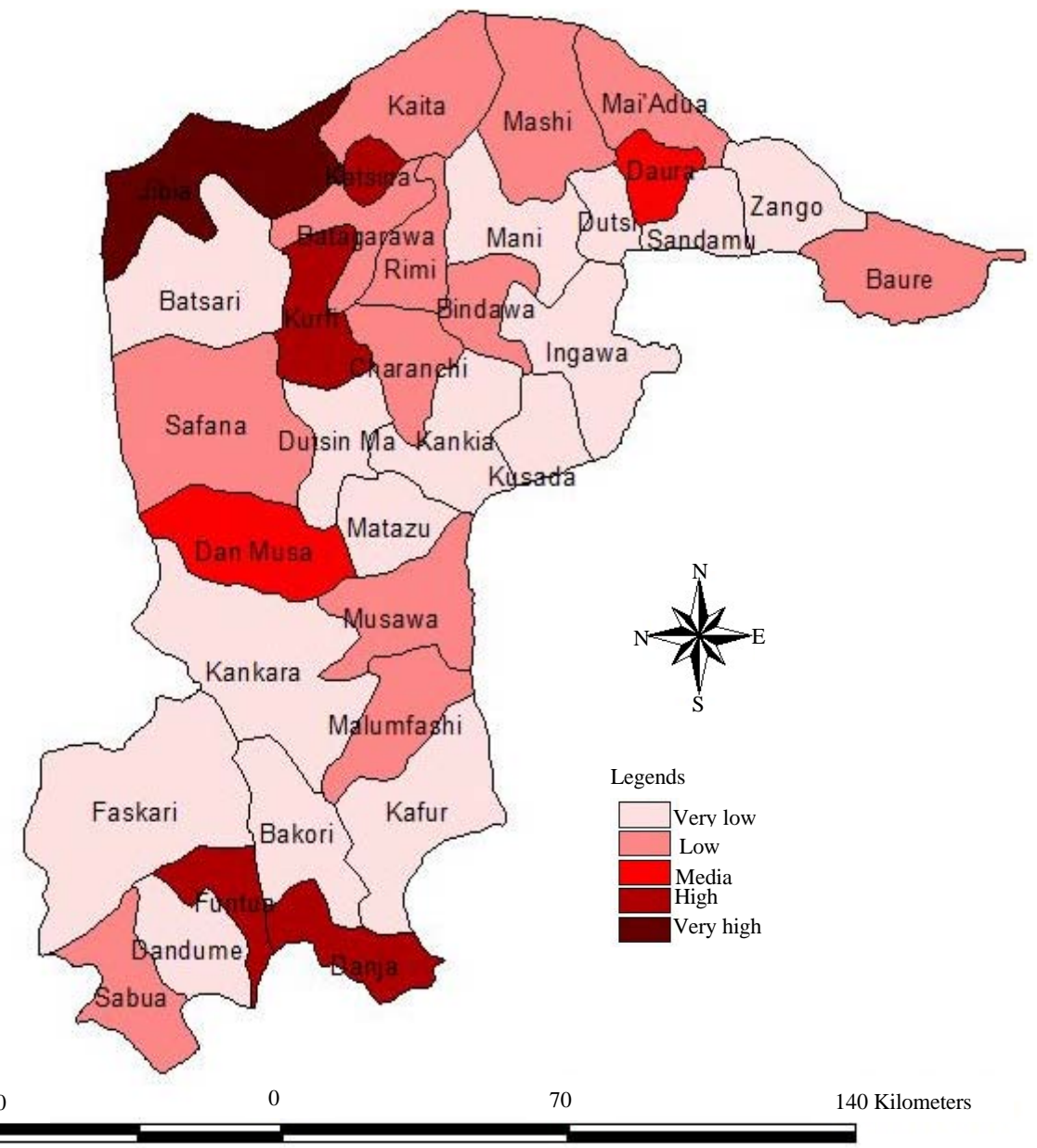

Fig. 5: Average rape rates in Katsina state 2006-2008 
Fig. 7. The values for most of the LGAs falls below the central line and Dandume, Kankara, Katsina and Sabuwa LGAs fall above the UCL. The Range chart shows Charanchi, Dandume, Katsina, Kurfi, Mani, Mashi, Sabuwa and Zango LGAs have much variation of rape cases over the three years. The charts have many LGAs above the UCL and with much variation over the period,
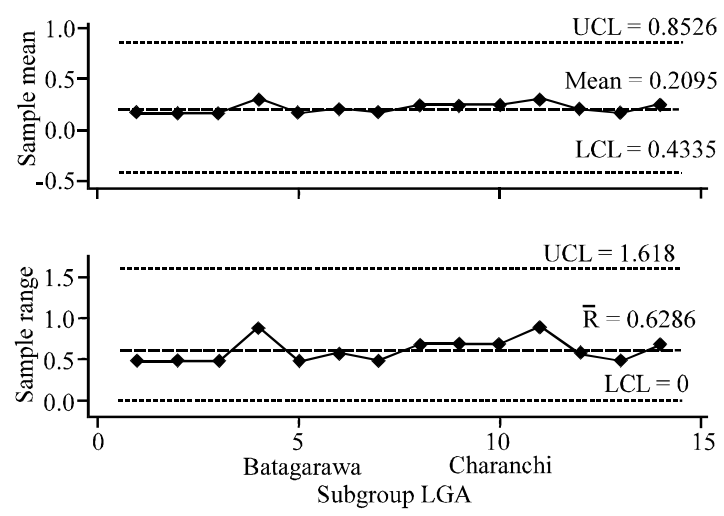

Fig. 6: Mean and range charts for median and low rape cases in Katsina state the mean and range charts for the LGAs with median rape cases from the GIS classifications would be constructed as standard measure (Fig. 8).

The LGAs with higher GHW cases from Fig. 5 are Katsina and Kurfi from ACl, Sabuwa and Kankara from $\mathrm{AC} 2$ and Mashi from $\mathrm{AC} 3$ whereas being very higher in Dandume LGA.

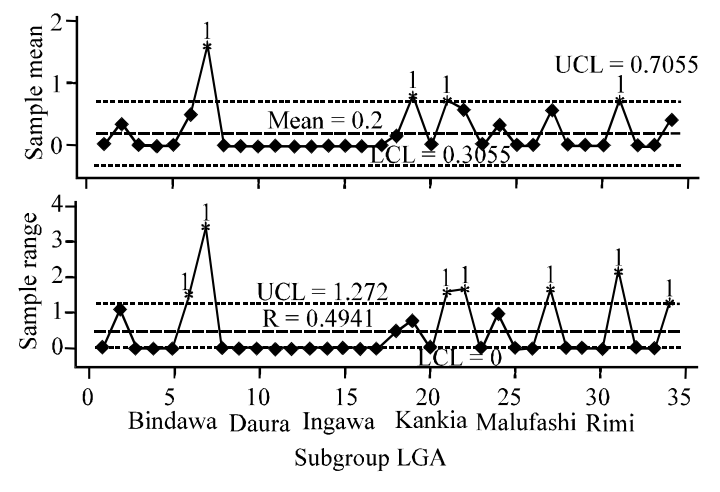

Fig. 7: Mean and range charts for GHW cases in Katsina state

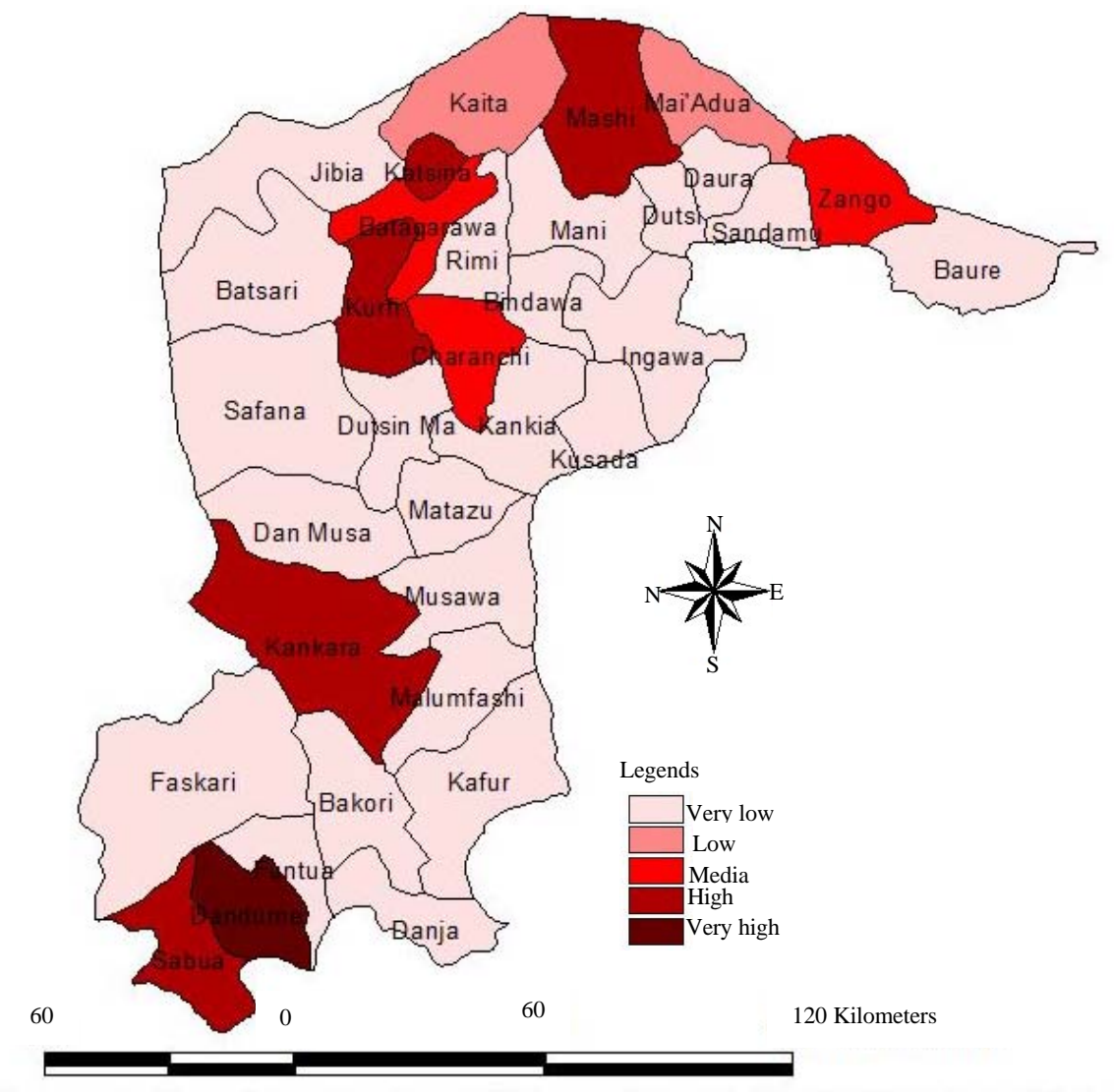

Fig. 8: Average grievous hurt and wounding rates in Katsina state 
The LGAs with median rates are Charanchi and Batagarawa from $\mathrm{ACl}$ and Zango from $\mathrm{AC} 3$ while being lower in Kaita and Maiaduwa LGAs. The rest of the LGAs have very lower rates. The crime is more prevalence in the LGAs located at the northern part of $\mathrm{ACl}$ and 3.

From the GIS classification, the mean and range charts for the LGAs with median GHW cases are constructed in Fig. 9 as standard measure for monitoring

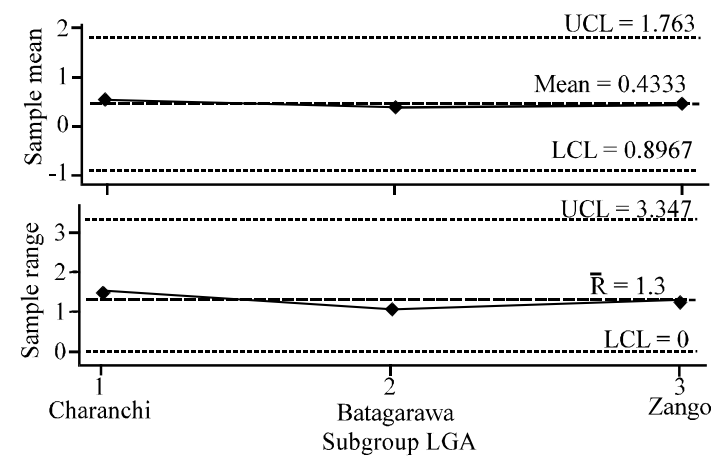

Fig. 9: Mean and Rates charts for median GHW cases in Katsina state rape cases. The historical mean value is 0.4333 . The mean and range charts for assault cases in Katsina state is plotted on Fig. 10.

The values for most of the LGAs falls below the central line and Katsina LGA fall above the UCL. The LGAs with high variability over the 3 years that fall above the UCL of the range chart are Bakori, Batsari, Daura, Funtua, Kusada and Zango LGAs. The mean chart

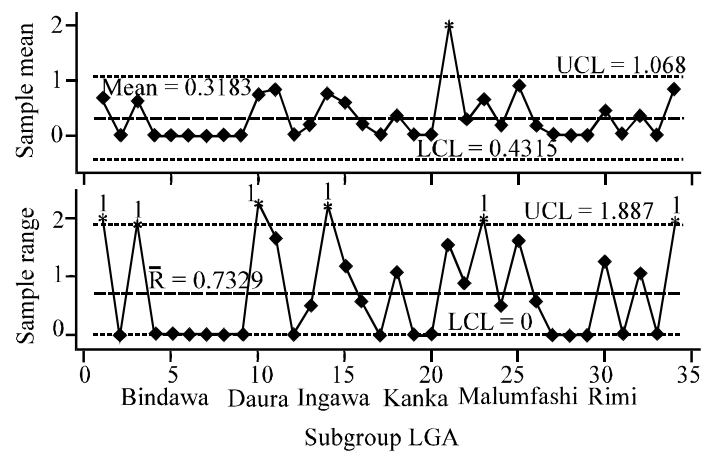

Fig. 10: Mean and range charts for assaults cases in Katsina state

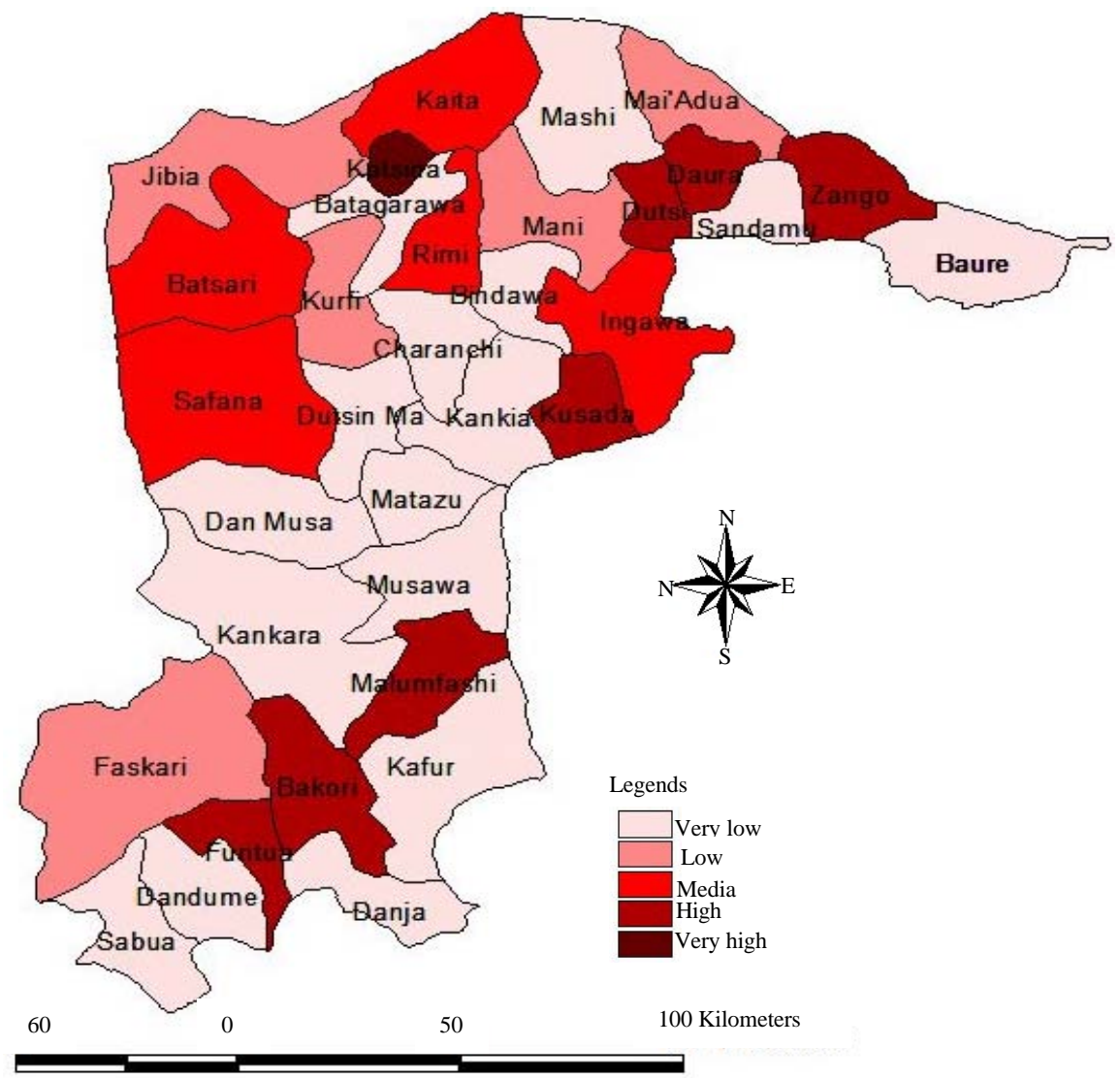

Fig. 11: Average assault rates in Katsina state 2006-2008 


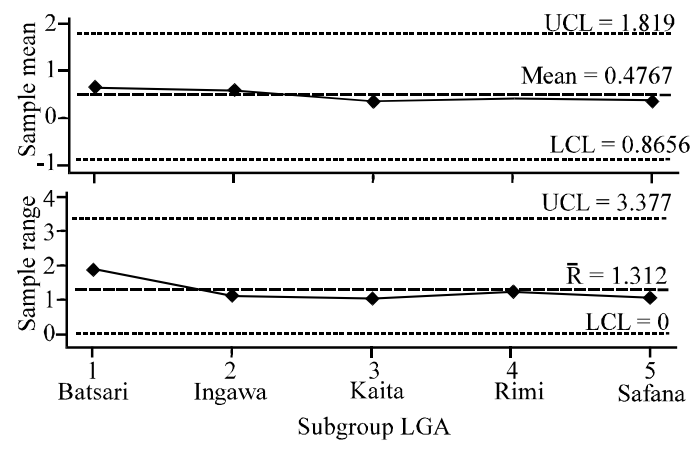

Fig. 12: Mean and range charts for median assault cases in Katsin state
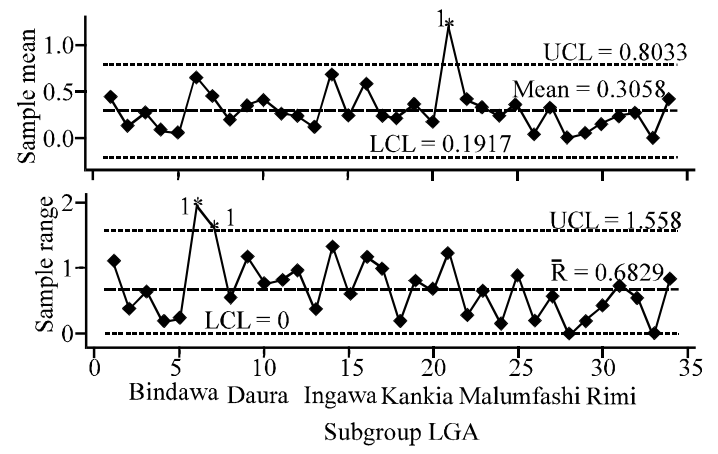

Fig. 13: Mean and range charts crimes against persons in Katsina state

shows Katsina LGA beyond the control limits and many LGAs have much variation over the period as shown from the range chart.

Therefore, the mean and range charts for the LGAs with median rape cases from the GIS classifications would be constructed as standard measure. From Fig. 11, the LGA with very higher rate of assault cases is Katsina LGA while being higher in Funtua, Bakori and Malumfashi from AC2, Kusada, Zango, Dutsi and Daura from AC3 and with median rates in Batsari, Safana, Kaita and Rimi from ACl and Ingawa from AC3. The rates are lower in Maiadua, Mani, Kurfi, Jibia and Faskari LGAs where the rest of the LGAs have very lower rates.

The northerly $\mathrm{ACl}$ and 3 have the higher prevalence of the crime than the southerly AC2 and the LGAs located at the central part of the state have very lower rate of the crime.

From the GIS classification, the mean and range charts for the LGAs with median assault cases are constructed in Fig. 12 as standard measure of assessing rape cases in Katsina state. The historical mean value is 0.4767. In Fig. 12, researcher construct the general control chart for assessing crimes against persons in Katsina state in the future years by taking the four crimes as

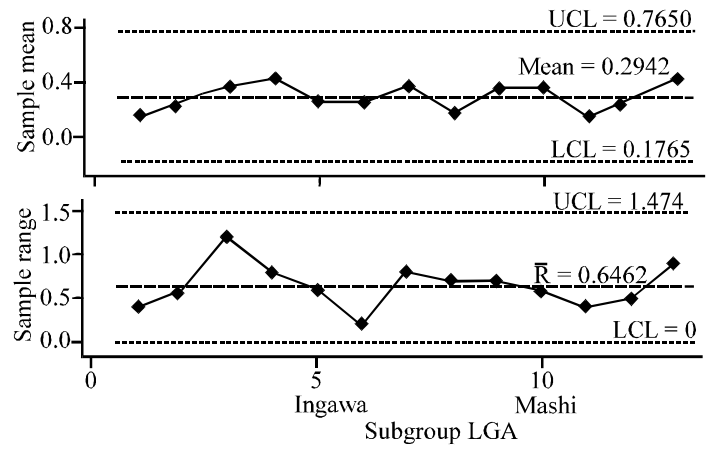

Fig. 14: Mean and range charts for median crimes against persons in Katsina state

measurements. The mean chart in Fig. 13 has shown Charanchi, Funtua and Jibia LGA with very high crime rates while Katsina LGA is even beyond the UCL. The LGAs with very lower rate of crimes are Baure, Bindawa, Mani and Sandamu LGAs, all of them from AC3. The range chart has shown Charanchi and Dandume with very high variability beyond the UCL.

The aim is to construct a standard chart with LGAs that have median crime rates with less variability, therefore researcher combine the LGAs with median rates of the crimes under study. The LGAs are in the order: Batsari, Batagarawa, Daura, Danmusa, Ingawa, Kaita, Kankara, Kankia, Kusada, Mashi, Rimi, Safana and Zango LGAs.

The mean and range charts are constructed in Fig. 14 as standard measure of monitoring crimes against persons in Katsina state in the future years. The historical mean value is 0.2942 .

\section{CONCLUSION}

Crime control and prevention of criminal activities from very higher levels to very lower levels is gradual in nature. The police need modern methods for monitoring criminal activities in a given area. This study is an effort to illustrate how control charts and GIS classifications can be utilized in monitoring crime rate in Katsina state.

\section{REFERENCES}

Ahamad, B., 1967. An analysis of crimes by the method of principal components. J. R. Applied Stat., 16: 17-35.

Borowick, K.S., 1997. Analysis of low probability count data with applications in Crime Analysis. Baylor University, Waco, Texas, Pages: 346.

Carvell, I.G. and G.E. Swinfen, 1970. Criminal law and Procedure. Sweet and Maxwell, London. 
Danbazau, A.B., 2007. Criminology and Criminal Justice. 2nd Edn., Spectrum Books Limited, Ibadan.

Duncan, A.J., 1986. Quality Control and Industrial Statistics. 5th Edn., Irwin, Homewood, IL.

Durkheim, E., 1933. The Division of Labour in Society. G. Simpson (trans.), New York, Macmillan.

Fajemirokun, F., O. Adewale, T. Idowu, A. Oyewusi and B. Maiyegun, 2006. A GIS approach to crime mapping and management in Nigeria: A case study of Victoria Island Lagos. Proceedings of the Conference on Shaping the Change and XXIII FIG Congress, October 8-13, 2006, Munich, Germany, pp: 1-17.

Feldman, M.P., 1997. The Psychology of Crime. University Press, Cambridge.

Hardle, W. and H. Zdenek, 2007. Multivariate Statistics: Exercises and Solutions. Springer-Verlag, New York.

Kpedekpo, G.M.C. and P.L. Arya, 1981. Social and Economics Statistics for Africa. George Allen and Unwin, London.

Lind, D.A. and R.D. Mason, 1997. Basic Statistics for Business and Economics. 7th Edn., McGraw-Hill Company, New York.
Louis, S., W.S. Cookie, A.Z. Louis and R.E. Sheldon, 1981. Human Response to Social Problems. The Dorsey Press, Illinois.

McGuffog, I., J.S. Western and P. Mullins, 2001. Exploratory spatial data analysis techniques for examining urban crime. Br. J. Criminol., 41: 309-329.

Radzinowicz, L. and L. King, 1977. The Growth of Crime: The International Experience. Hamish Hamilton, London, Pages: 15.

Rencher, A.C., 2002. Methods of Multivariate Analysis. 2nd Edn., John Wiley and Sons, New York, pp: 451-503.

Savoie, J., 2008. Analysis of the spatial distribution of crime in Canada: Summary of major trends. Stat. Canada Catal., 2008: 85-561.

Tsiamtsiouri, A. and J. Panaretos, 1999. Some statistical analysis of greek crime data. Proceedings of the International Conference Envirometrics and Statistics in the Earth and Space Sciences, August, 1999, Athens, Greece. 